\title{
Profile of women with cervical cancer attended for treatment in oncology center
}

Ruan Carlos Gomes da Silva 1

Amanda Cristina de Oliveira Silva 2

Adrya Lúcia Peres 3

Sibele Ribeiro de Oliveira 4

1,2,4 Centro Universitário Tabosa de Almeida. Av. Portugal, 584. Bairro Universitário. Caruaru, PE, Brasil. CEP: 55.016-400. E-mail: ruuancarlooss@gmail.com ${ }^{3}$ Instituto de Estudos avançados ASCES-UNITA. Caruaru, PE, Brasil.

\begin{abstract}
Objectives: to evaluate the sociodemographic, clinical, histopathological, cytopathological and microbiological profile of women with cervical cancer treated at Oncology Center in Pernambuco, located in the city of Caruaru-PE.

Methods: a retrospective study was carried out to evaluate the medical records of women with cervical cancer treated for radiotherapy and/or chemotherapy between January 2014 and December 2016. For the analysis of variables, the absolute and relative frequencies were calculated.

Results: there was a predominance of cases in the age range between 40 and 59 years (45.37\%), non-white race/color (91.75\%) and incomplete primary education (44.32\%). Squamous carcinoma was present in $85.19 \%$ of the cases, with a moderately differentiated histological grade being the most common (53.41\%). Most women underwent radiotherapy and associated chemotherapy (72.72\%) and had 3 or more pregnancies before diagnosis (73.44\%). Cytopathology has more frequently identified high-grade squamous intraepithelial lesion (HSIL) cases (45.83\%) and cocci and/or bacilli (66.67\%) were the most evident microorganisms.

Conclusions: the results showed that the perimenopause age, low educational level, multiparity, cytopathologic result of HSIL and histopathological examination evidencing moderately differentiated squamous cell carcinoma were among the characteristics most related to cervical cancer in the population studied.

Key words Uterine cervical neoplasms, Women's health, Histopathology, Carcinoma, squamous cell, Cytopathology
\end{abstract}




\section{Introduction}

Cervical cancer is considered an important public health problem, especially in the less developed regions, being the third most frequent tumor in the female population, after breast and colon and rectum cancer. ${ }^{1}$

The number of new cases of cervical cancer expected in Brazil in the 2018-2019 biennium is 16,370 , with an estimated risk of 15.43 cases per 100,000 women. Statistics from the National Cancer Institute (INCA) for the state of Pernambuco estimates 1,030 new cases, which represents an incidence rate of 20.84 cases per 100,000 women. ${ }^{2}$

The persistence of infection by the Human Papillomavirus (HPV) is considered the main predisposing factor for cervical cancer, since through microleads in the squamous epithelium, the virus can penetrate, reach basal cells, release its DNA and replicate. The cells then suffers accelerated maturation and multiplication, induced by viral oncoproteins, developing intraepithelial lesions, which may evolve into a malignant neoplastic process. ${ }^{3}$

Studies have shown that only HPV infection does not justify cervical carcinogenesis, being necessary to be associated with risk factors, such as early beginning of sexual activity, multiplicity of sexual partners, multiparity, prolonged use of oral contraceptives, smoking, nutritional deficiency and immunological status. 4

The literature has demonstrated a strong association between multiparity and intraepithelial lesions, increasing the risk of developing cervical cancer fourfold, justified by the hormonal, traumatic and immunological factors of pregnancy. 5

Inflammatory processes that affect the cervix, mainly due to etiologic agents related to sexually transmitted infections (STIs) or opportunistic infections of the genitourinary tract, are also considered as cofactors to the development of cervical neoplasia due to the disorder in the vaginal microbiota, with reduction of Lactobacillus sp. and an increase in obligate anaerobic agents, which may promote an increased risk of HPV infection. ${ }^{6}$ Bacterial vaginosis can cause damage to the vaginal epithelium, degrading cervical mucus, altering the physicalchemical and immunological environment and inhibiting chemotaxis of leukocytes, due to the synthesis of succinic and acetic acids, that could influence HPV infection and persistence. ${ }^{7}$ Several studies have demonstrated an association between bacterial vaginosis and HPV infection in the development of intraepithelial lesions, revealing association in almost $38 \%$ of cases. 8,9
Cytopathology is the choice method for the tracking of intraepithelial lesions precursors of cervical cancer, as well as contributing to recognition of infectious and/or inflammatory conditions. ${ }^{10}$ In view of the beginning of an increasingly earlier and often unprotected sexual life, the favoring infection by HPV and other sexually transmitted microorganisms occurs, making clear the importance of using this test in tracking and prevention campaigns. ${ }^{11}$

Histopathological examination is considered the gold standard for diagnosis of cervical cancer, allowing, in the practice of care, to classify the type and histological grade of tumors and to provide a basis for clinical and therapeutic decisions. 12

Most women with cervical cancer have, according to epidemiological data of the literature, age between 40 and 50 years, marking the end of their reproductive life, nonwhite color, low level of both schooling and home occupation, evidencing that the high prevalence of the disease is associated with the population's life conditions, access to public health services, and quality of women's health care. 13

With the purpose of supporting the understanding of cervical cancer in Agreste Pernambucano (a region in Pernambuco, a Brazilian State), allowing for improvements in screening and prevention programs, this study aimed to evaluate the sociodemographic, clinical, histopathological, cytopathological and microbiological profile of women with cervical cancer uterus which were attended and underwent treatment at an oncology center, located in the city of Caruaru, Pernambuco.

\section{Methods}

It is a documentary, descriptive, exploratory and retrospective research, carried out after approval of the Committee of Ethics in Research with Human Beings of the University Center Tabosa de Almeida Asces-Unita ( $\left.\mathrm{n}^{\circ} 1.823 .743\right)$. The sample consisted of medical records of women with cervical cancer, confirmed by histopathology, attended at a Center of Oncology of Agreste Pernambucano, between January 2014 and December 2016.

Data from medical records of women assisted by the oncology center and treated for chemotherapy and/or radiotherapy of cervical cancer were collected. The sample was given for convenience, including the medical records of women treated in the proposed period, in any age group, excluding cases that started treatment in another institution and that, therefore, did not have enough data for analysis in their medical records. 
Socio-demographic variables, including age, race/color of the skin, degree of education and marital status were analyzed from the charts; clinical variables such as number of pregnancies and treatments performed; histopathological variables, such as type and histological grade; and cytopathological variables, including outcome, epithelia represented in the cervical sample and microorganisms identified morphologically by cytopathological examination. Some variables, although included in the study, did not present completeness in all evaluated charts.

In relation to the variable treatment, only medical records that presented, at the histopathological examination, information about histological grade of the tumors were considered for analysis, given the importance of this variable for the clinical definition of the treatment.

For the data analysis, the absolute (n) and relative (\%) frequencies of the quantitative variables were calculated. The data obtained was organized in the Microsoft Office Excell 2016 for Windows.

\section{Results}

A total of 140 women were attended at the Oncology Center of Agreste Pernambucano for treatment of cervical cancer from January 2014 to December 2016. The present study was composed of 108 medical records of women attended in this period, with $32(22.86 \%)$ medical records being excluded from the study because they had incomplete data since the women had been treated at another institution.

The average age at diagnosis was 50.65 years (standard deviation $[\mathrm{SD}] \pm 5.66$ ). Concerning the sociodemographic profile, there was a predominance of women between the ages of 40 and $59(45.37 \%)$, non-white race/color $(91.75 \%)$ and incomplete elementary school (44.32\%) (Table 1).

As to the histopathological examination, 92/108 $(85.19 \%)$ presented squamous carcinoma and $14 / 108$ $(12.96 \%)$ adenocarcinoma. The histological grade of the tumors was evidenced in $88 / 108$ reports, of which $47 / 88$ (53.41\%) presented a moderately differentiated grade (histological grade II) and 25/88 (28.41\%) undifferentiated grade III.

Regarding the treatments performed, 64/88 (72.72\%) women had concomitant radiotherapy and chemotherapy and 13/88 (14.78\%) had radiotherapy, chemotherapy and hysterectomy surgery. Most of the women had 3 pregnancies or more 47/64 (73.44\%) (Table 2).

Results of cytopathological examination were found in only $24 / 108(22.22 \%)$ medical records, being that $11 / 24(45.83 \%)$ presented high-grade squamous intraepithelial lesion (HSIL) and 9/24 (37.5\%) squamous carcinoma. As to the representativity of the epithelia in the cytopathological sample, it was verified that in $11 / 24(45.84 \%)$ samples there was representation of squamous and glandular epithelium and 9/24 (37.5\%) only squamous epithelium.

As to the profile of microorganisms morphologically identified by cytopathology, cocci and/or bacillus predominated $(66.67 \%)$, followed by Gardnerella vaginalis (8.33\%), despite a significant percentage of undetermined cytopathologies microbiological profile $(20.83 \%)$ (Table 3 ).

\section{Discussion}

In the present study, a mean age for diagnosis of 50.65 years was observed. A similar result was found in a study conducted in São Paulo by Thuler et al.,14 which evaluated the sociodemographic characteristics of women with cervical cancer in Brazil, showing an average age of 49.2 years.

Current recommendations of the Brazilian guidelines for the tracking of cervical cancer recommend cytopathological examination in women aged 25 to 64.10 In this study, $45.37 \%$ of women were aged between 40 and 59 years. However, it was evidenced that $20.37 \%$ of women diagnosed with cervical cancer were older than 64 years, suggesting that many may not have been included in the tracking program, so, in a way, it is not possible to detect intraepithelial lesions before they become invasive lesions.

Thuler et al.,15 analyzing the determinants of the advanced stage diagnosis in women with cervical cancer in Brazil, showed an average age of $52.4 \pm$ 14.1 and established a relation that women aged between 30 and 39 years would have a $10 \%$ greater chance of developing advanced disease, increasing gradually up to 2 times for the age group of 60 years or more, concluding, therefore, that age is one of the main predictors of moderate and advanced disease.

A predominance of non-white women (91.75\%) was found, approaching the results of Carvalho and Queiroz ${ }^{16}$ and Ribeiro et al.,17 who found a frequency of $63.3 \%$ and $82.1 \%$, respectively, of women of non-white color in the existence of the diagnosis. However, in contrast to these results, Carmo and Luiz ${ }^{18}$ showed a predominance of the white race $(55.5 \%)$ in women diagnosed with cervical cancer and treated at the National Cancer Institute, Rio de Janeiro, justifying the use of race/color as a social marker more related to envi- 
Absolute and relative frequency of sociodemographic variables of women with cervical cancer treated during the period from 2014 to 2016

\begin{tabular}{|c|c|c|}
\hline Variables & $\mathbf{N}$ & $\%$ \\
\hline \multicolumn{3}{|l|}{ Age at diagnosis (years) } \\
\hline$\leq 29$ & 9 & 8.33 \\
\hline 30 to 39 & 19 & 17.60 \\
\hline 40 to 49 & 27 & 25.00 \\
\hline 50 to 59 & 22 & 20.37 \\
\hline 60 to 69 & 15 & 13.89 \\
\hline 70 to 79 & 14 & 12.96 \\
\hline 80 years and over & 2 & 1.85 \\
\hline Total & 108 & 100.0 \\
\hline \multicolumn{3}{|l|}{ Race/color of the skin } \\
\hline White & 8 & 8.25 \\
\hline Not White & 89 & 91.75 \\
\hline Total & 97 & 100.0 \\
\hline \multicolumn{3}{|l|}{ Degree of instruction } \\
\hline Unlettered & 21 & 23.86 \\
\hline Incomplete elementary school & 39 & 44.32 \\
\hline Complete primary education & 15 & 17.05 \\
\hline Incomplete high school & 2 & 2.27 \\
\hline Complete high school & 7 & 7.95 \\
\hline Higher education & 4 & 4.55 \\
\hline Total & 88 & 100.0 \\
\hline \multicolumn{3}{|l|}{ Conjugal State } \\
\hline Single & 44 & 41.90 \\
\hline Married & 43 & 40.96 \\
\hline Widow & 12 & 11.43 \\
\hline Divorced & 6 & 5.71 \\
\hline Total & 105 & 100.0 \\
\hline
\end{tabular}

\section{Table 2}

Absolute and relative frequency of clinical and histopathological variables of women with cervical cancer treated in the period from 2014 to 2016

\begin{tabular}{lcc}
\hline Variables & $\mathbf{N}$ & $\%$ \\
\hline Histological Type & & 85.19 \\
Squamous carcinoma & 92 & 12.96 \\
Adenocarcinoma & 14 & 1.85 \\
Adenosquamous carcinoma & 2 & 100.0 \\
Total & 108 & 18.18 \\
Histological Grade & & 53.41 \\
Well differentiaded (Grade I) & 16 & 28.41 \\
Moderately differentiaded (Grade II) & 47 & 100.0 \\
Undifferentiaded (Grade III) & 25 & \\
Total & 88 & 7.95 \\
Treatment (s) performed (s) & & 4.55 \\
Surgery & 7 & 72.72 \\
Radiotherapy & 4 & 14.78 \\
Radiotherapy/Chemotherapy & 64 & 100.0 \\
Radiotherapy/Chemotherapy/Surgery & 13 & 88 \\
Total & & \\
\hline
\end{tabular}


Absolute and relative frequency of clinical and histopathological variables of women with cervical cancer treated in the period from 2014 to 2016.

\begin{tabular}{lcc}
\hline Variables & $\mathbf{N}$ & $\%$ \\
\hline Number of pregnancies & & 1.56 \\
$\quad$ None & 1 & 9.38 \\
1 & 6 & 15.62 \\
2 & 10 & 73.44 \\
3 or more & 47 & 100.0 \\
Total & 64 & \\
\hline
\end{tabular}

Table 3

Absolute and relative frequency of the cytopathologic variables of women with cervical cancer treated in the period from 2014 to 2016.

\begin{tabular}{|c|c|c|}
\hline Variables & $\mathbf{N}$ & $\%$ \\
\hline \multicolumn{3}{|l|}{ Result if cytopathologic } \\
\hline Low Grade Squamous Intraepithelial Lesion (LSIL) & 3 & 12.50 \\
\hline High Grade Squamous Intraepithelial Lesion (HSIL) & 11 & 45.83 \\
\hline Squamous Carcinoma & 9 & 37.50 \\
\hline Adenocarcinoma & 1 & 4.17 \\
\hline Total & 24 & 100.0 \\
\hline \multicolumn{3}{|l|}{ Epithelia represented in the cervical sample } \\
\hline Squamous & 9 & 37.50 \\
\hline Squamous/Glandular & 11 & 45.84 \\
\hline Squamous/Glandular/Metaplastic & 2 & 8.33 \\
\hline Squamous/Metaplastic & 2 & 8.33 \\
\hline Total & 24 & 100.0 \\
\hline \multicolumn{3}{|l|}{ Identified microorganisms } \\
\hline Not rated & 5 & 20.83 \\
\hline Cocci & 10 & 41.67 \\
\hline Bacillus & 1 & 4.17 \\
\hline Gardnerella vaginalis & 2 & 8.33 \\
\hline Cocci e bacillus & 5 & 20.83 \\
\hline Cocci e Candida sp. & 1 & 4.17 \\
\hline Total & 24 & 100.0 \\
\hline
\end{tabular}

ronmental factors, contributing to the lack of access to cytopathological exams. However, it is worth noting that the race/color variable of this study is not self-declared, being evaluated according to the data found in medical records. Therefore, it was a limitation, where the relationship of this variable with cervical cancer can not be precisely defined.

It was found that illiterate womenand those with incomplete primary education accounted for $68.18 \%$ of women diagnosed with cervical cancer. Mascarello et al., 19 while describing the profile of women with cervical cancer treated at a philanthropic hospital in Vitória, Espírito Santo, found that $70.9 \%$ of the women were illiterate or had incomplete primary level, contributing to the high number of late diagnoses and, consequently, to the great number of relapses, metastases and deaths.

Akinyemiju et al. ${ }^{20}$ analyzed socioeconomic and educational status throughout life cycle in relation to the tracking of breast and cervical cancer in women in India, China, Mexico, Russia and South Africa, revealing that women with a higher grade of individual and parental education were 10 times more likely to participate in tracking programs for breast and cervical cancer compared to women with low socioeconomic and educational status. In this study, while screening rates were $5.1 \%$ for illiterate women, it rose to $39.6 \%$ and $51.1 \%$ in women with secondary/high school and post-graduate education, respectively.

Squamous carcinoma was the most frequent histological type $(85.19 \%)$ and the moderately 
differentiated histological grade was evidenced in $53.41 \%$ of the reports, followed by the undifferentiated grade with $28.41 \%$. In agreement with these data, Zhou et al. ${ }^{21}$ also identified squamous carcinoma as the most frequent in the studied population (86\%), followed by adenocarcinoma $(10.6 \%)$ and adenosquamous carcinoma (3.4\%). These authors also demonstrated that a great part of women with adenocarcinoma and adenosquamous carcinoma had a well differentiated histological grade, whereas the tumors with a diagnosis of squamous carcinoma had a differentiation degree of moderate and undifferentiated, revealing, through univariate and multivariate analyzes, that the histological grade may interfere with the prognosis of women with squamous cell carcinoma.

The most commonly used treatment modality in women in this study was radiotherapy associated with chemotherapy $(72.72 \%)$. The use of antineoplastic chemotherapy with a cisplatin protocol associated with brachytherapy has been shown to be very promising, since it has allowed an increase in the individual response to therapy and reduced the volume of tumor mass for subsequent surgery, if necessary. 22 Furthermore, the combination of chemotherapy and radiation allows an overall survival benefit of $8-9 \%$ for the interval without local recurrence. 23

Regarding the number of pregnancies, this study revealed that $73.44 \%$ of women diagnosed with cervical cancer had 3 or more pregnancies. Barroso et al.,24 analyzing the frequency of cytopathological examination in young people aged 17 to 22 years in Teresina, Piauí, observed that multiparity should be considered a risk factor for the inadequate collection frequency for cytopathological examination, since the higher the number of pregnancies among adolescents, the greater the probability of acquiring HPV infection, and the lower the number of prenatal consultations, due to restrictions because of taking care of another child, as well as the activities of the home, with consequent reduction of possibilities for conducting exams, increasing 2.2 times the probability of developing HSIL and invasive cancer.

The HSIL result was the most frequent in the evaluated cytopathological examinations (45.83\%), followed by squamous carcinoma (37.5\%). All women included in the study had the diagnosis of cervical cancer confirmed by histopathology, but in $58.33 \%$ of cases, cytopathology was not able to identify cervical neoplasia. This can be justified by the fact that $55.70 \%$ of the cases of squamous cell carcinoma presented moderate differentiation and $29.11 \%$ undifferentiated in histopathology, as well as $55.56 \%$ of adenocarcinoma cases also presented a moderate to undifferentiated histologic grade, which may have contributed to the difficulty in identifying cytoplasmic and nuclear malignancy criteria. Even so, cytopathology acts in the identification of highgrade intraepithelial lesions, which allow the woman to be assisted and accompanied by specialized services in gynecology. 25

In addition, in some cases where the representativeness of the sample contributed to the non-identification of cervical neoplasia, it was observed that the cytopathological reports were represented only by ectocervix material, which were released with HSIL and LSIL (Low Grade Squamous Intraepithelial Lesion) results, but the histopathology revealed that it was actually adenocarcinoma. According to Gasparin et al.,26 the squamocolumnar junction $(\mathrm{SCJ})$ and/or transformation zone are regions where more than $90 \%$ of the intraepithelial lesions are located, demonstrating the need for constant monitoring and qualification of the professionals involved in the collection of cytopathological material, so that the involvement of the cervical smears is avoided. 26

Factors such as subjectivity, training, experience, cytopathologist scrutiny ability, work overload, SCJ cells representativeness, adequate fixation, diagnostic difficulties (few scaly abnormal cells, small or inaccessible lesions, necrosis, bleeding, origin of lesions, diagnoses borderline), in addition to internal and external laboratory quality control, are essential for the screening of cervical cancer and, if not taken into account, may induce errors in the interpretation of cytomorphological criteria, making it impossible to carry out complementary tests and clinical followup of cervical cancer in women. 27

Regarding the microorganisms morphologically identified by cytopathology, this study verified the predominance of cocci and/or bacilli (66.67\%), followed by Gardnerella vaginalis $(8.33 \%)$. The cocci and/or bacilli were more frequently present in cytopathologies of women aged 40 to 49 years $(20.83 \%)$, in addition to the highest percentage in reports with HSIL results $(33.33 \%)$.

Confronting these results, Castro-Sobrinho et $a l ., 28$ evaluating cervical smears of HPV-infected women, found that Gardnerella vaginalis was the most frequent microorganism in smears with invasive carcinoma (18.2\%) and HSIL (45.6\%), concluding that bacterial vaginosis, may be associated with the severity of cervical neoplasia.

The infectious agents that affect the cervix are defended by several studies as being cofactors in the pathogenesis of cervical cancer, persistence, 
progression and carcinogenesis induced by HPV. Some species of bacteria and fungi are capable of causing changes and epithelial damage, protein degradation and increased antigenic response, leading to cervical mucosal injury and endogenous invasion of opportunistic microorganisms. In addition, the accumulation of free radicals, caused by genital infections, increases the virulence of HPV, the susceptibility of the organism and induces the proliferation of altered cells. ${ }^{29,30}$

This study revealed that perimenopausal age, low educational level, low social status, multiparity, cytopathologic result of HSIL, histopathological examination evidencing moderately differentiated

\section{References}

1. Melo TFV, Bezerra HS, Silva DGKC, Silva RAS Epidemiological profile of women with HPV treated in a basic health unit. Rev Fund Care Online. 2016; 8 (4): 517783.

2. Estimativa 2018: incidência de câncer no Brasil / Instituto Nacional de Câncer José Alencar Gomes da Silva. Coordenação de Prevenção e Vigilância - Rio de Janeiro: INCA, 2017.

3. Libera LSD, Alves GNS, Souza HG, Carvalho MAS Avaliação da infecção pelo Papiloma Vírus Humano (HPV) em exames citopatológicos. Rev Bras Anal Clin. 2016; 48 (2): 138-43.

4. Muentes GDG, Rodríguez LKG, Galarraga RIB, Carpio FA, Cabezas JCR. Genotypes distribution of human papillomavirus in cervical samples of Ecuadorian women. Rev Bras Epidemiol. 2016; 19 (1): 160-6.

5. Anjos SJSBA, Vasconcelos CTM, Franco ES, Almeida PC, Pinheiro AKB. Fatores de risco para câncer de colo do útero segundo resultados de IVA, citologia e cervicografia. Rev Esc Enferm USP. 2010; 44 (4): 912-20.

6. Alves JAB, Nunes MS, Fakhouri R, Martins-Filho PRS, Ribeiro COM, Valença TS, et al. Frequency of Gardnerella vaginalis, Candida spp., Trichomonas vaginalis and pill use or copper intrauterine device use. Int Arch Med. 2016; 9 (360): 1-6.

7. Silva C, Almeida ECS, Côbo EC, Zeferino VFM, Murta EFC, Etchebehere RM. A retrospective study on cervical intraepithelial lesions of low-grade and undetermined significance: evolution, associated factors and cytohistological correlation. Sao Paulo Med J. 2014; 132 (2): 92-6.

8. Peres AL, Camarotti JRSL, Cartaxo M, et al. Molecular analysis and conventional cytology: association between HPV and bacterial vaginosis in the cervical abnormalities of a Brazilian population. Genet Mol Res. 2015; 14 (3): 9497-505.

9. Caixeta RCA, Ribeiro AA, Segatti KD, Saddi VA, Figueiredo Alves RR, Santos Carneiro MA, Rabelo-Santos $\mathrm{SH}$. Association between the human papillomavirus, bacterial vaginosis and cervicitis and the detection of abnormalities in cervical smears from teenage girls and young women. Diagn Cytopathol. 2015; 43 (10): 780-85. squamous carcinoma and morphological identification of cocci and/or bacilli were among the characteristics more related to cervical cancer in the studied population.

The data obtained point to the need to implement educational actions on prevention, contributing, consequently, to the greater adherence of these women to the tracking and diagnostic exams, allowing the reduction of mortality rates and sequels caused by cancer. In this context, national programs need to provide better conditions for implementing health policies and access to public health services, promoting early detection and timely treatment.

10. Diretrizes brasileiras para o rastreamento do câncer do colo do útero / Instituto Nacional do Câncer José Alencar Gomes da Silva. Coordenação de Prevenção e Vigilância. Divisão de Detecção Precoce e Apoio à Organização de Rede.- $2^{a}$ ed rev atual - Rio de Janeiro; INCA, 2016.

11. Aguilar RP, Soares DA. Barreiras à realização do exame Papanicolau: perspectivas de usuárias e profissionais da Estratégia de Saúde da Família da cidade de Vitória da Conquista-BA. Physis. 2015; 25 (2): 359-79.

12. Altuve MA, Monsalve N, Noguera ME. Incidencia de adenocarcinoma de cuello uterino en el Instituto Autónomo Hospital Universitario de Los Andes. Rev Obstet Ginecol Venezuela. 2014; 74 (3): 162-79.

13. Rangel G, Lima LD, Vargas EP. Condicionantes do diagnóstico tardio do câncer cervical na ótica das mulheres atendidas no Inca. Saúde Debate. 2015; 39 (107): 1065-78.

14. Thuler LCS, Bergmann A, Casado L. Perfil das pacientes com câncer de colo do útero no Brasil, 2000-2009: estudo de base secundária. Rev Bras Cancerol. 2012; 58 (3): 3517

15. Thuler LCS, Aguiar SS, Bergmann A. Determinantes do diagnóstico em estádio avançado do câncer do colo do útero no Brasil. Rev Bras Ginecol Obstet. 2014; 36 (6): 237-43.

16. Carvalho MCMP, Queiroz ABA. Mulheres portadoras de lesões precursoras do câncer do colo do útero e HPV: descrição do perfil socioeconômico e demográfico. J Bras Doenças Sex Transm. 2011; 23 (1): 28-33.

17. Ribeiro JF, Silva ARV, Campelo VC, Santos SLD, Coelho DMM. Perfil sociodemográfico e clínico de mulheres com câncer do colo do útero em uma cidade do Nordeste. Rev Gestão Saúde. 2015; 6 (2): 1367-81.

18. Carmo CC, Luiz RR. Survival of a cohort of women with cervical cancer diagnosed in a Brazilian cancer center. Rev Saúde Pública. 2011; 45(4): 661-7.

19. Mascarello KC, Silva NF, Piske MT, Viana KCG, Zandonade E, Amorim MHC. Perfil sociodemográfico e clínico de mulheres com câncer do colo do útero associado ao estadiamento inicial. Rev Bras Cancerol. 2012; 58 (3): 417-26.

20. Akinyemiju T, Ogunsina K, Sakhuja S, Ogbhodo V, 
Braithwaite D. Life-course socioeconomic status and breast and cervical cancer screening: analysis of the WHO's Study on Global Ageing and Adult Health (SAGE). BMJ Open. 2016; 6 (11).

21. Zhou J, Wu SG, Sun JY, Li FY, Lin HX, Chen QH, He ZY. Comparison of clinical outcomes of squamous cell carcinoma, adenocarcinoma, and adenosquamous carcinoma of the uterine cervix after definitive radiotherapy: a population-based analysis. J Cancer Res Clin Oncol. 2017; 143 (1): $115-22$.

22. Frigo LF, Zambarda SO. Câncer do colo de útero: efeitos do tratamento. Cinergis. 2015; 16 (3): 164-8.

23. Sadalla JC, Andrade JM, Genta MLND, Baracat EC Cervical cancer: what's new? Rev Assoc Med Bras. 2015; 61 (6): 536-42

24. Barroso MF, Gomes KRO, Andrade JX. Frequência da colpocitologia oncótica em jovens com antecedentes obstétricos em Teresina, Piauí, Brasil. Rev Panam Salud Publica. 2011; 29 (3): 162-8.

25. Amorim CPS, Monteiro ABC, Siqueira GIMR, Coelho RA. Mulheres submetidas à conização de colo uterino: análise dos resultados citológico e histopatológico. Rev Med UFC. 2015; 55 (1): 13-7.

26. Gasparin VA, Pitilin EB, Bedin R, Metelski FK, Geremia DS, Filho CCS. Fatores associados à representatividade da zona de transformação em exames citopatológicos do colo uterino. Cogitare Enferm. 2016; 21 (2): 1-9.
27. Prado PR, Koifman RJ, Santana ALM, Silva IF Caracterização do perfil das mulheres com resultado citológico ASCUS/AGC, LSIL e HSIL segundo fatores sociodemográficos, epidemiológicos e reprodutivos em Rio Branco - AC, Brasil. Rev Bras Cancerol. 2012; 58 (3): 471 9.

28. Castro-Sobrinho JM, Rabelo-Santos SH, Fugueiredo-Alves $\mathrm{RR}$, et al. Bacterial vaginosis and inflammatory response showed association with severity of cervical neoplasia in hpv-positive women. Diagnostic Cytopathology. 2015; 44 (2): 80-6.

29. Ghosh I, Mandal R, Kundu P, Biswas J. Association of genital infections other than Human Papilomavirus with pre-invasive and invasive cervical neoplasia. J Clin Diagn Res. 2016; 10 (2): 1-6.

30. Piyathilake CJ, Ollberding NJ, Kumar R, Macaluso M, Alvarez RD, Morrow CD. Cervical microbiota associated with higher grade cervical intraepithelial neoplasia in women infected with high-risk human Papillomaviruses. Cancer Prev Res. 2016; 9 (5): 357-66.

Received on October 25, 2017

Final version presented on September 11, 2018

Approved on September 28, 2018 